\title{
Sputum induction in children
}

\author{
Leader of the Working Group: P.G. Gibson* \\ Members of the Working Group: D.C. Grootendorst", ${ }^{\#, ~ R . L . ~ H e n r y ~}{ }^{+}$, I. Pin ${ }^{\S}$, P.H. Rytila ${ }^{f}$, \\ P. Wark**, N. Wilson"\# ${ }^{\# \text { R. Djukanović }}{ }^{\oplus}$
}

Sputum induction has been used to study asthma in children since the first description of the technique in 1992 [1]. Since then, $>20$ reports (five reviews) have appeared in the literature describing sputum induction in children with airways disease. In general, sputum induction in children of $>6 \mathrm{yrs}$ is safe and has a satisfactory success rate.

Approximately 500 children have been studied by sputum induction. The diagnoses of the studied children include stable asthma $(n=308)$, acute asthma $(n=18)$ and healthy control subjects $(n=185)$. Studies have included children aged 5-18 yrs, with a mean age of 11.2 yrs. Most studies have included children of $>6$ yrs. Studies of children with asthma have included subjects across the spectrum of severity.

The following issues regarding sputum induction in children are reviewed in the present article: 1) protocols used in children; 2) safety of induction; 3) management of airway obstruction during sputum induction; 4) sputum processing; 5) normal values in children; 6) findings in asthmatic children; 7) effect of treatment on induced sputum parameters; and 8) clinical applications.

\section{Sputum induction protocols used in children}

A wide variety of sputum induction protocols have been reported successful in children (table 1). There is great variation as to the brands of nebuliser used. All of the studies have used ultrasonic nebulisers, but these were either high- or low-output devices. Hypertonic saline has been used either at $4.5 \%$ (in four studies) or by increasing concentrations from 3 to 4 and then $5 \%$. Increasing concentrations of saline were used in five studies. Pretreatment with $\beta_{2}$-agonists has been applied in most $(\sim 80 \%)$ studies. Two studies used a combination of hypertonic saline challenge and sputum induction to assess airway hyperresponsiveness and, at the same time, induce sputum [5, 12].

The reported success rate of sputum induction in children is $68-100 \%$. To keep children enthusiastic throughout the induction procedure, it may help to show a cartoon video during nebulisation. Monitoring of lung function is considered essential to ensuring the safety of sputum induction. During sputum induction, lung function has been monitored by peak expiratory flow (three studies) or forced expiratory volume in one second (FEV1) (seven studies).

\section{Safety of sputum induction in children}

In general, sputum induction in children is a safe procedure. Reported side-effects include cough, airway obstruction, vomiting and anxiety. The procedure should be conducted by trained staff who are experienced in lung function measurement in children, and the identification and management of adverse effects in children. With $\beta_{2}$-agonist pretreatment, a fall in lung function of $>10 \%$ of baseline is seen in only $6 \%$ of children. Without $\beta_{2}$-agonist pretreatment, a greater proportion of children experience a reduction in lung function; however, this is readily reversed with inhaled $\beta_{2}$-agonists. Pretreatment with bronchodilators improves the success and tolerability of challenge in children [15].

\section{Management of airway obstruction during sputum induction}

When airway obstruction develops during sputum induction, nebulisation should cease and the child be treated with inhaled $\beta_{2}$-agonist. Salbutamol $(200 \mu \mathrm{g})$ via pressurised inhaler and spacer, or salbutamol (2.5$5 \mathrm{mg}$ ) via nebuliser, can be given. Oxygen may be

\footnotetext{
*Dept of Respiratory and Sleep Medicine, John Hunter Hospital, Newcastle, New South Wales, Australia. ${ }^{\#}$ Dutch Asthma Centre, Davos, Switzerland. "Dept of Pulmonology, Leiden University Medical Centre, Leiden, the Netherlands. ${ }^{+}$Sydney Children's Hospital, University of New South Wales, Sydney, Australia. ${ }^{\circledR}$ Dept of Paediatrics, CHU of Grenoble, Grenoble, France. ${ }^{f}$ Dept of Allergology, Helsinki University Central Hospital, Helsinki, Finland. **Southampton University, Southampton, UK. \#\# Dept of Paediatrics, Royal Postgraduate Medical School, Hammersmith Hospital, London, UK. "Southampton University General Hospital, Southampton, UK
}

Correspondence: P. Gibson, Dept of Respiratory and Sleep Medicine, John Hunter Hospital, Locked Bag No. 1 HRMC, NSW 2310, Australia. Fax: 612 49213469. E-mail: mdpgg@mail.newcastle.edu.au

Received: April 4 2002; Accepted: April 162002 
Table 1. - Sputum induction in children with asthma and controls

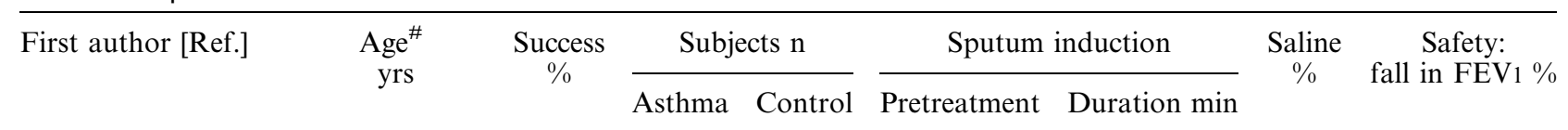

\begin{tabular}{|c|c|c|c|c|c|c|c|c|}
\hline PIN [1] & $13.5(11-16)$ & 76 & 13 & 26 & $\mathrm{Y}$ & 30 & $3,4,5$ & NR \\
\hline TWADDELL [2] & $12(8-15)$ & 92 & 8 & 0 & $\mathrm{Y}$ & $20^{\bullet}$ & 0.9 & 5.3 \\
\hline PIACENTINI [3] & $10.7(11-14)$ & 100 & 16 & 0 & $\mathrm{Y}$ & 20 & 4.5 & $<10$ \\
\hline SORVA [4] & $9.1(7-11)$ & 76 & 14 & 15 & NR & NR & 5 & NR \\
\hline GIBSON [5] & $11(8-14)$ & 92 & 61 & 109 & $\mathrm{~N}$ & $15.5^{\star}$ & 4.5 & NR \\
\hline JONES [6] & $9(8.3-13.9)$ & 100 & 1 & 0 & $\mathrm{Y}$ & 8 & 4.5 & NR \\
\hline CAI [7] & $12(6-18)$ & 84 & 50 & 72 & Y & $15.5^{\star}$ & 4.5 & NR \\
\hline PIACENTINI [8] & $12(8-13)$ & 100 & 9 & 0 & $\mathrm{Y}$ & 20 & 4.5 & $<10$ \\
\hline MATTES [9] & $11.2(6-16)$ & 96 & 25 & 9 & Y & 30 & $3,4,5$ & $<15$ \\
\hline PIACENTINI [10] & NR (6-13) & 81 & 25 & 0 & $\mathrm{Y}$ & 20 & 4.5 & NR \\
\hline LONNKVIST [11] & $12(9-14)$ & 100 & 10 & 0 & NR & 20 & 3,5 & NR \\
\hline Он [12] & $14(11-14)$ & 100 & 30 & 14 & $\mathrm{~N}$ & NR & 4.5 & NR \\
\hline GROOTENDORST [13] & $15(12-18)$ & 95 & 20 & 0 & Y & $15^{\circ}$ & 4.5 & 4 \\
\hline GIBSON [14] & $12(8-17)$ & 88 & 42 & 0 & $\mathrm{Y}$ & $15.5^{\bullet}$ & 0.9 & NR \\
\hline
\end{tabular}

FEV1: forced expiratory volume in one second; Y: yes; NR: not reported; N: no. ${ }^{\#}$ : mean or median (range); ${ }^{\natural}$ : maximum duration.

necessary in a severe episode. The response to treatment should be monitored by peak expiratory flow or FEV1. $\beta_{2}$-Agonist administration can be repeated if there is an incomplete response.

\section{Sputum processing}

Induced sputum from children has been processed using the selected portion technique in $>80 \%$ of studies. Two studies used the whole expectorate method [12, 13]. Dispersal of cells has been performed using dithiothreitol in all studies. In children with cystic fibrosis, dispersal with dithiothreitol was found to be inferior to dispersal using enzymes [16]. The reproducibility of induced sputum cell counts in children has been reported in only two studies [1, 17]. A variety of methods have been used to assess sputum quality. The quality of induced sputum samples in children is reported as good to satisfactory in most cases; however, data are seldom provided to support this. In particular, the extent of salivary contamination, as reflected by squamous cell counts, has been reported as part of a component quality score in four studies [1, 5-7, 17]. Most studies have not reported the extent of salivary contamination or the sputum volume obtained.

\section{Normal values in children}

Values from normal/healthy children have been reported by CAI et al. [7], with an upper limit for sputum eosinophil percentage of 2.5. Centres differ in the type of healthy children that may be included as normal.

\section{Findings in asthmatic children}

Children with stable asthma exhibit increased eosinophil number and may exhibit increased bronchial epithelial cell number in their sputum [7, 8]. In acute asthma, there are increased numbers of eosinophils and mast cells and eosinophil cationic protein concentrations. Some children exhibit accompanying sputum neutrophilia with increased levels of interleukin-8 [18]. Children with asymptomatic airway hyperresponsiveness show normal cell counts [17]. Children with cystic fibrosis have intense sputum neutrophilia [16].

\section{Effects of treatment on induced sputum parameters}

There have been no controlled studies reporting the effects of treatment on sputum parameters in children. Uncontrolled studies suggest that sputum eosinophil numbers fall with corticosteroid therapy [4, 12, 18].

\section{Clinical applications}

There have been no studies reporting the clinical application of induced sputum analysis in children.

\section{Key points}

1) Sputum induction can be performed safely in children, and has acceptable risks. 2) The procedure should be performed by technologists who are trained and have sufficient experience in conducting the procedure in children. 3) The safety and procedural requirements are similar to those for adults. It is necessary to standardise the sequence of inhalation, measure airway function during induction, use an ultrasonic nebuliser with a sufficient and measured output, and use adequate instruments and facilities. 4) Pretreatment with bronchodilators improves the success and tolerability of sputum induction in children. 5) Sputum eosinophilia characterises asthma in children, where it is related to asthma severity and falls with corticosteroid therapy. 


\section{Outstanding issues}

1) What is the reproducibility of cell numbers/fluidphase markers in children? 2) What is the influence of age upon success, cell counts, side-effects and reproducibility? 3) Can sputum induction be successfully performed in subjects of $<6$ yrs? 4) Can pharyngeal secretions or secretions collected by physiotherapy from young children be used as a surrogate for induced sputum in infants? 5) What are the potential clinical applications of sputum induction in children? 6) Do different induction/processing methods give different results in children? 7) Does sputum induction have a research/clinical role in children with other conditions such as severe asthma, cystic fibrosis and other chronic lung diseases? 8) Is it necessary to monitor oxygenation during sputum induction? If so, when? 9) What is the maximum dose of hypertonic saline that should be administered? 10) What are the effects of repeat sputum induction on success, cell counts and fluid-phase markers? 11) Does it take longer to induce sputum/teach expectoration in children than in adults? 12) Is there any difference between high- and low-output nebulisers in terms of success and/or side-effects? 13) Is there any effect of differing saline concentration in children? 14) What is the best means of assessing sputum quality? Does it differ between children and adults?

\section{References}

1. Pin I, Gibson PG, Kolendowicz R, et al. Use of induced sputum cell counts to investigate airway inflammation in asthma. Thorax 1992; 47: 25-29.

2. Twaddell SH, Gibson PG, Carty K, Woolley KL, Henry RL. Assessment of airway inflammation in children with acute asthma using induced sputum. Eur Respir J 1996; 9: 2104-2108.

3. Piacentini GL, Martinati L, Mingoni S, Boner AL. Influence of allergen avoidance on the eosinophil phase of airway inflammation in children with allergic asthma. J Allergy Clin Immunol 1996; 97: 1079-1084.

4. Sorva R, Metso T, Turpeinen M, Juntunen-Backman $\mathrm{K}$, Bjorksten F, Haahtela T. Eosinophil cationic protein in induced sputum as a marker of inflammation in asthmatic children. Pediatr Allergy Immunol 1997; 8: 45-50.

5. Gibson PG, Wlodarczyk JW, Hensley MJ, et al. Epidemiological association of airway inflammation with asthma symptoms and airway hyperresponsiveness in childhood. Am J Respir Crit Care Med 1998; 158: 36 41.

6. Jones PD, Henry RL, Gibson PG, Hankin R, Carty $\mathrm{K}$. Chemotherapy for malignancy induces a remission in asthma symptoms and airway inflammation but not airway hyperresponsiveness. Pediatr Pulmonol 1998; 26: $74-77$.

7. Cai Y, Carty K, Henry RL, Gibson PG. Persistence of sputum eosinophilia in children with controlled asthma when compared with healthy children. Eur Respir J 1998; 11: 848-853.

8. Piacentini GL, Vicentini L, Mazzi P, Chilosi M, Martinati L, Boner AL. Mite-antigen avoidance can reduce bronchial epithelial shedding in allergic asthmatic children. Clin Exp Allergy 1998; 28: 561-567.

9. Mattes J, Storm van's Gravesande K, Reining U, et al. NO in exhaled air is correlated with markers of eosinophilic airway inflammation in corticosteroiddependent childhood asthma. Eur Respir J 1999; 13: 1391-1395.

10. Piacentini GL, Bodini A, Costella S, et al. Exhaled nitric oxide and sputum eosinophil markers of inflammation in asthmatic children. Eur Respir $J$ 1999; 13: 1386-1390.

11. Lonnkvist K, Hallden G, Dahlen SE, et al. Markers of inflammation and bronchial reactivity in children with asthma, exposed to animal dander in school dust. Pediatr Allergy Immunol 1999; 10: 45-52.

12. Oh JW, Lee HB, Kim CR, et al. Analysis of induced sputum to examine the effects of inhaled corticosteroid on airway inflammation in children with asthma. Ann Allergy Asthma Immunol 1999; 82: 491496.

13. Grootendorst DC, van den Bos JW, Romeijn JJ, et al. Induced sputum in adolescents with severe stable asthma. Safety and the relationship of cell counts and eosinophil cationic protein to clinical severity. Eur Respir J 1999; 13: 647-653.

14. Gibson PG, Norzila MZ, Fakes K, Simpson J, Henry RL. Pattern of airway inflammation and its determinants in children with acute severe asthma. Pediatr Pulmonol 1999; 28: 261-270.

15. Jones PD, Hankin R, Simpson J, Gibson PG, Henry RL. The tolerability, safety, and success of sputum induction and combined hypertonic saline challenge in children. Am J Respir Crit Care Med 2001; 164: 11461149.

16. Cai YC, Carty K, Gibson PG, Henry RL. Comparison of sputum processing techniques in cystic fibrosis. Pediatr Pulmonol 1996; 22: 402-407.

17. Pin I, Radford S, Kolendowicz R, et al. Airway inflammation in symptomatic and asymptomatic children with methacholine hyperresponsiveness. Eur Respir J 1993; 6: 1249-1256.

18. Norzila MZ, Fakes K, Henry RL, Simpson J, Gibson PG. Interleukin-8 secretion and neutrophil recruitment accompanies induced sputum eosinophil activation in children with acute asthma. Am J Respir Crit Care Med 2000; 161: 769-774. 